\title{
Self-Perceptions on Digital Competences for M-Learning and Education Sustainability: A Study with Teachers from Different Countries
}

\author{
Manuel Alejandro Betancourt-Odio ${ }^{1}$ (D), Andresa Sartor-Harada ${ }^{2, *(D)}$, Oscar Ulloa-Guerra ${ }^{3}(\mathbb{D})$ \\ and Juliana Azevedo-Gomes 4 (iD
}

check for updates

Citation: Betancourt-Odio, M.A.; Sartor-Harada, A.; Ulloa-Guerra, O.; Azevedo-Gomes, J. Self-Perceptions on Digital Competences for M-Learning and Education Sustainability: A Study with Teachers from Different Countries.

Sustainability 2021, 13, 343.

https://doi.org/10.3390/su13010343

Received: 13 November 2020

Accepted: 28 December 2020

Published: 2 January 2021

Publisher's Note: MDPI stays neutral with regard to jurisdictional clai$\mathrm{ms}$ in published maps and institutional affiliations.

Copyright: $(2021$ by the authors. Licensee MDPI, Basel, Switzerland. This article is an open access article distributed under the terms and conditions of the Creative Commons Attribution (CC BY) license (https:// creativecommons.org/licenses/by/ $4.0 /)$.
1 Quantitative Methods Department, Universidad Pontificia Comillas, 28015 Madrid, Spain; mabetancour@@icade.comillas.edu

2 Education Faculty, Universidad Internacional de la Rioja, 26006 Logroño, Spain

3 General Didactic Department, Universidad Internacional de La Rioja, 26006 Logroño, Spain; oscar.ulloa@unir.net

4 Teacher Training Department, Universidad Europea del Atlántico, 39011 Santander, Spain; juliana.azevedo@uneatlantico.es

* Correspondence: andresa.sartor@unir.net

\begin{abstract}
The current international landscape shows that the most common alternative for the continuity of formative learning processes during the coronavirus pandemic has been the use the of e-learning to support children's learning in environments outside of school. This forced change in teaching methods has consolidated the recognition that the digital skills of teachers are a relevant factor for the sustainability of education, both during the pandemic and in a future post-pandemic period or in other emergencies. In this sense, the objective of this study carried out between May and September 2020 was to determine the perceptions of 427 teachers from 15 countries about their digital competences in working with m-learning in primary education using a Montessori approach. The results of the questionnaire showed that teachers perceive their digital competences as inert and not very effective for innovation compared with the subsistence of traditional pedagogical practices, to deal with unpredictable situations or to generate differentiated adaptations for an inclusive education. The results of this study also serve as empirical support for establishing four training dimensions that can be considered priorities for the construction and implementation of a teacher training model that contributes to the sustainable development of education.
\end{abstract}

Keywords: digital competences; m-learning; sustainable learning process; teacher training; primary education; Montessori principles

\section{Introduction}

Given the global concern about the effects of the coronavirus crisis on education, multiple calls have emerged to stimulate scientific production on the subject, including calls from journals to submit articles, hold academic events, project financing, and organization of panels in television programs. We are, without a doubt, before a thematic field of current relevance due to its high implications for sustainable development.

The UN has highlighted the need to respond to this demand with an overwhelming fact: changes in the dynamics of educational processes because of the pandemic have affected more than $91 \%$ of students worldwide [1]. In this sense, even though the particularities of each country have been decisive, the most recurrent alternative to confinements associated with the pandemic has been non-face-to-face education supported by e-learning, causing a forced change in the teaching modalities and forms of interaction between teachers, students, and families [2-4].

There are several signs of the collapse of educational systems when assuming what some scientists have called an e-learning emergency for the continuity of training processes 
during the pandemic [5-9]. Even [10] had already warned about the relevance of this factor for the sustainability of education, observing that, despite the advantages, the number of teachers who use this type of technology was limited, and was therefore consciously integrated with avant-garde methodological and pedagogical principles. Along this line of analysis, UNESCO has highlighted a lack of pedagogical transformation in which technologies end up occupying a marginal place in educational practices [11]. Other studies have also revealed difficulties for teachers to effectively use technological tools introduced in the classrooms, affecting the stability and sustainability of educational processes [12].

Therefore, the educational treatment of digital technologies in the classroom does not comprise simply in the introduction of certain technical tools, programs, or applications, but implies a transformation in the teaching-learning process and the transmission of information in order to integrate it into a pedagogical and methodological approach. It is precisely the lack of an innovative and sustainable pedagogical approach that does not allow the working process with ICTs to be efficient. ICTs in education are still considered technologies through which information is accessed and transmitted, and not as real tools that enable meaningful learning or the improvement of the teaching-learning process [13].

Even the presence of mobile phones in the classroom, so far, is frowned upon within the educational community. On the one hand, there are conservative attitudes that prohibit their use in schools, while others believe that the current classroom ecosystem has been enriched in recent years by the mass arrival of mobile phones [14]. Far from being a nuisance, they could be an opportunity for learning and motivating the development of a teaching modality more focused on the individual needs of students, while also developing an approach adapted to virtual reality and the presence of mobile phones [15].

M-learning allows us to combine several methodologies and learning strategies in line with the profiles and learning needs of students. To this end, m-learning seeks to integrate learning theories, especially constructivist and behavioral ones, with the aim of creating collaborative work environments [16]. Therefore, talking about the mere use of devices in the classroom as a synonym of m-learning is no longer possible. We must now demand that these devices be accompanied by a pedagogical approach and/or an educational framework that results in some improvement of the educational process [17].

Digital technologies have created many expectations, but approaches have focused on adapting to pre-existing school formats, without encouraging improvements in learning, while affecting educational sustainability.

It is not a question of changing the notebook for a tablet, a computer, or a smartphone, but adapting the technological tools to specific educational objectives and, thus, contributing to an improvement by incorporating a clear work methodology using ICTs [18].

For a quality and innovative education, the obstacles to be faced should be taken into account so that it lasts over time, involving the educational community in the management of the quality of services and paying special attention to the competitiveness of teachers [19]. When teachers have skills for m-leaning, there are better conditions for integrating ICTs in a critical, sustainable, and communal way [20]. Educational sustainability means that it is inclusive, equitable, egalitarian, and of good quality, evidencing a harmony with the perspective that defines the objectives for sustainable development [21,22].

In other words, thinking about sustainable education today encompasses two main areas: the role of education in promoting a sustainable developmental approach, and the very sustainability of educational systems based on the three core elements of inclusion, equality, and good quality. Is it possible to ignore the central role of mobile technologies as key factors for the inclusion, equality, and good quality of education? We have defended the idea that moving toward sustainable education requires that the value of technologies and the digital skills of teachers be fully considered. Both are key elements in transcending from a mere teacher of rote to one of an ICT user who can act in innovative ways to avoid the collapse of educational processes and to ensure sustainability in the face of unforeseen events, such as the current pandemic [23]. 
The cited research highlights the need to problematize the sustainability of educational systems, paying special attention to the key factors for their consolidation. The unpredictability of the pandemic, and the uncertainty that accompanies it, requires research that contributes to obtaining data and projection of strategies for the sustainability of education, both during the coronavirus pandemic and in a future post-pandemic period or in the face of other emergencies.

In the direction of problematizing the sustainability of education, this article presents the results of international research carried out in the context of Project Koulu (ID19-XX003), funded by SODERCAN in Santander, Spain. The objective of the study was to analyze the perceptions of teachers from 15 countries about their digital skills for working with m-learning in primary education using a sustainable Montessori approach. M-learning is learning through digital mobile environments, making it possible to acquire, interrelate, and share new knowledge through mobile devices (tablets, computers, smartphones, phablets, netbooks, etc.) [24].

The analyses showed that teachers self-perceive their digital skills for m-learning as stagnant and ineffective for innovation, dealing with unpredictable situations, or generating differentiated adaptations to digital gaps. They served as empirical support to establish four dimensions training that will be the basis of a model of teacher training under construction as a contribution of Project Koulu to the sustainable development of education.

\section{Background Literature Review}

The inquiries undertaken integrated two factors that we considered key for the sustainability of education: the digital competencies of teachers to work with m-learning, and the integration of Montessori principles. Both elements had to be assumed in an interwoven way, since little progress has been made toward a sustainable management of education with teachers who limit themselves to integrating technologies for the subsistence of traditional practices that do not promote significant learning or stimulate innovation from ethical-humanist paradigms $[25,26]$.

It adopted the UNESCO Model of ICT Standards and Competencies, a model of ICT skills for teaching based on the levels of appropriation of ICTs. This model integrates the teaching skills for the design, implementation and evaluation of educational practices supported by ICT, and the different modalities of knowledge representation (know, use, and transform). At the initial level of appropriation (integration), teachers use ICT as a tool to optimize the presentation of content, communication, and transmission of information. At advanced levels of appropriation (reorientation and evolution), the internal dynamics of educational practices are enhanced by the inclusion of ICTs. ICTs become tools that facilitate the construction of knowledge (reorientation) or even become powerful mediating tools that generate unthinkable dynamics without the presence of ICTs (evolution). It was possible to summarize these competencies in Figure 1.

\begin{tabular}{|c|c|c|c|c|c|c|c|c|c|}
\hline \multirow{3}{*}{$\begin{array}{c}\text { ICT } \\
\text { Competence }\end{array}$} & \multicolumn{9}{|c|}{ LEVEL OF APPROPRIATION } \\
\hline & \multicolumn{3}{|c|}{ Integration } & \multicolumn{3}{|c|}{ Reorientation } & \multicolumn{3}{|c|}{ Evolution } \\
\hline & Know & Use & Transform & Know & Use & Transform & Know & Use & Transform \\
\hline Design & Descriptors & Descriptors & Descriptors & ” & " & " & , & " & " \\
\hline Implement & " & " & " & " & $"$ & " & ” & " & , \\
\hline Evaluate & $"$ & $"$ & $"$ & , & $"$ & " & $"$ & $"$ & " \\
\hline
\end{tabular}

Figure 1. Components of the Model of ICT Standards and Competencies. Levels of the appropriation of ICTs from the pedagogical dimension based on the levels of appropriation [27].

A relationship was established between the benefits of the Montessori method and learning with mobile devices in primary education. Starting from a predominantly con- 
structivist approach, Montessori pedagogy provided strategies that supported teachers in the development of methodologies that integrated mobile technology into educational activities in the primary classroom [28,29].

In line with the constructivist approach, the Montessori method was developed from the design of an open learning environment (the prepared environment) and the production of learning objects (the Montessori materials), organizational bases that we evaluated as being conducive to the inclusion and sustainability of ICTs in the daily work of teachers in the classroom. The Montessori method brought the possibility of transforming work methodologies with mobile devices to improve the education process.

The principles of Montessori education were included, in connection with the educational possibilities offered by m-learning and, specifically, with mobile devices in the classroom:

- The student's personal choice;

- Collaborative learning;

- Self-direction;

- The teacher as a guide

- Learning by discovery [30].

Montessori pedagogy was intended to promote development and learning through non-intrusive educational interventions. This means that the teacher can provide different educational possibilities, thereby constructing learning situations [31].

In this sense, from the systematization of digital competences for m-learning and the principles of Montessori pedagogy, eight units of analysis were determined within the framework of this study (Figure 2).
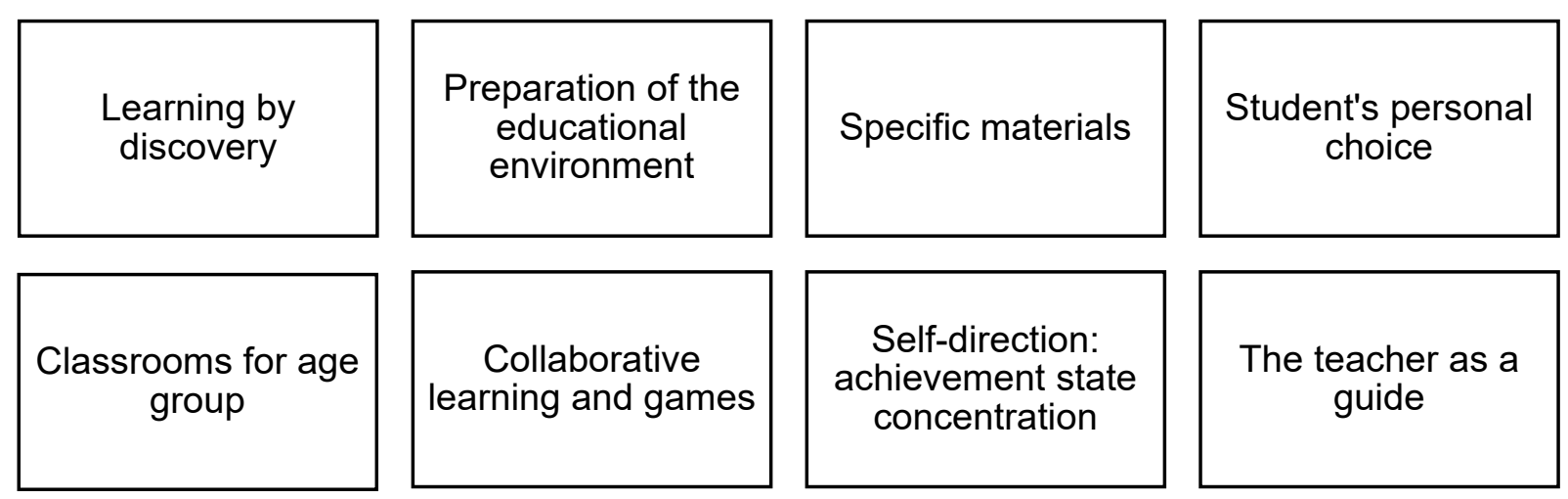

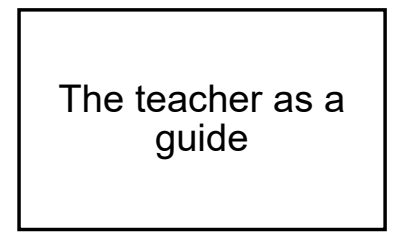

Figure 2. Elements of Montessori pedagogy that contribute to teacher development in m-learning.

They are units of analysis that were considered productive to address the object of study of the project Koulu-digital skills of teachers to work with m-learning from a sustainable Montessori pedagogical perspective-and to define the five dimensions of analysis:

Dimension 1-Theory and knowledge about digital competence;

Dimension 2-Analysis and selection of resources;

Dimension 3-Design and development of resources;

Dimension 4-Applying and evaluating resources;

Dimension 5-Pertinence and integration of the principles of Montessori education.

\section{Materials and Methods}

To carry out the study that is described in this article, a mixed methodological perspective (quantitative-qualitative) was adopted to meet the proposed objective: to analyze the perceptions of teachers from 15 countries about their digital competences for working with m-learning using a sustainable Montessori approach in primary education (level of education predominantly attended by students between 6 and 11 years old). 
A non-probabilistic sampling was applied. The assumed selection technique was that of accessibility, taking into account the possibility of contact with teachers from several countries who were studying postgraduate studies in virtual platforms of institutions linked to Project Koulu (European University of the Atlantic, Spain and International Ibero-American University, Mexico). This obtained a sample of 427 teachers from primary educational institutions in Honduras, Colombia, Ecuador, El Salvador, Guatemala, Nicaragua, Peru, Dominican Republic, Chile, Brazil, Angola, Mozambique, Portugal, and Spain, configuring a study with results of an international scope. Table 1 shows the composition of the sample according to the country of residence.

Table 1. Composition of the sample according to the country of residence.

\begin{tabular}{cccccc}
\hline \multirow{2}{*}{ Country } & \multicolumn{2}{c}{ MEN } & \multicolumn{2}{c}{ WOMEN } & Total \\
& Absolute f. & \% & Absolute f. & \% & by Country \\
\hline Honduras & 15 & 13 & 60 & 19 & 75 \\
Colombia & 22 & 18 & 41 & 13 & 63 \\
Ecuador & 10 & 8 & 35 & 11 & 45 \\
El Salvador & 0 & 0 & 12 & 4 & 12 \\
Guatemala & 2 & 2 & 9 & 3 & 11 \\
Nicaragua & 3 & 3 & 8 & 2.5 & 11 \\
Peru & 8 & 6 & 12 & 4 & 20 \\
Dominican Rep. & 0 & 0 & 6 & 2.5 & 6 \\
Chile & 10 & 8 & 13 & 4.5 & 23 \\
Brazil & 25 & 20 & 73 & 23 & 98 \\
Angola & 9 & 7 & 14 & 5 & 23 \\
Mozambique & 4 & 4 & 4 & 1.5 & 8 \\
Portugal & 2 & 2 & 5 & 2 & 7 \\
Spain & 11 & 9 & 14 & 5 & 25 \\
Total & 121 & 29 & 306 & 71 & 427 \\
\hline
\end{tabular}

To collect data on the teachers' perceptions of their digital skills for working with m-learning from a sustainable Montessori perspective, a questionnaire with closed and open questions was constructed that covered the five dimensions of analysis mentioned (theory and knowledge about digital competence, analysis and selection of resources, design and development of resources, applying and evaluating resources, and pertinence and integration of the principles of Montessori education).

Content validation of the instrument was carried out through the judgment of $10 \mathrm{ex}-$ perts from the area of education and technology with mastery of the aspects that cover the theoretical support of the instrument-digital competences for m-learning and the Montessori approach - in order to recognize a sustainable relationship between the two.

The application of the questionnaire was developed during May and June 2020. The analysis and interpretation of the results was carried out between July and September 2020. For this last procedure, the Google tool was used for the identification and grouping of quantitative data and the ATLAS.ti program, version 6.0, for the systematic analysis of the transcripts and the grouping of the comments, in order to obtain proper interpretations and to subsequently establish the conclusions of the study.

\section{Results and Discussion}

Figure 3 shows the results obtained, taking as a reference the indicated dimensions and integrating the answers obtained in the questionnaires applied to the teachers. It deals with the percentages obtained for the first dimension. 


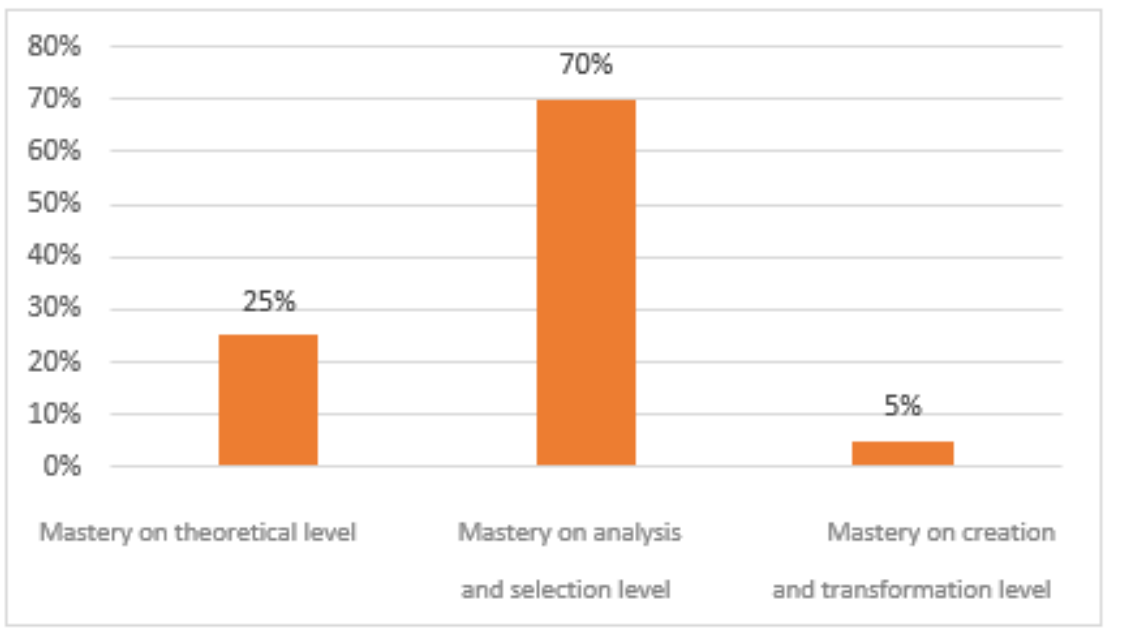

Figure 3. Dimension 1: Theory and knowledge about digital competence.

Figure 3 shows the data collected about the metacognition of the teachers and their perceptions of knowledge regarding the theories related to digital competence, showing that a large part of the studied teaching group (70\%) affirmed and believed that they controlled and presented the domain necessary both for the analysis and for the selection of a technology to be implemented in their classes. A quarter of the sample claimed to stay at the theoretical level, which made the sustainability of the use of tools unfeasible, but on the contrary, $5 \%$ believed they go further and claimed to be able to carry out transformation processes based on the used technologies.

Figure 4 shows that, for the second dimension, the values between the first two levels began converging, with fewer teachers showing decision-making capacities for the selection of new technological tools to be implemented in the classroom. On the other hand, the number in the third level reached $9 \%$, which shows that there were more teachers in this dimension who would dare to propose transformations when selecting and analyzing ICT resources.

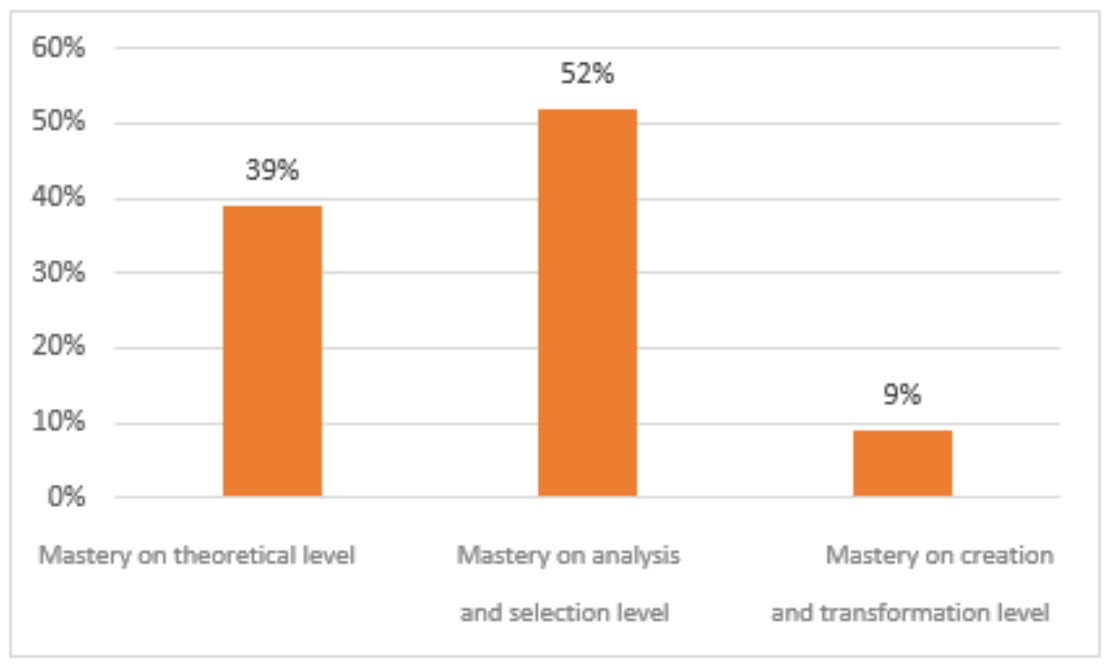

Figure 4. Dimension 2: Analysis and selection of resources.

Figure 5 shows that when developing and designing new technological resources for classroom work, the percentages followed, at a more equable level, the same structure of the previous dimensions, where most professionals claimed to have sufficient knowledge to analyze and select these designs and elaborations (45\%), while fewer would actually propose new creations or transformations of the pre-established designs for technological 
resources $(18 \%)$. It can be stated that most of the teachers considered that their competences were centered in the theoretical field of analysis and selection. This result is in line with other studies [32].

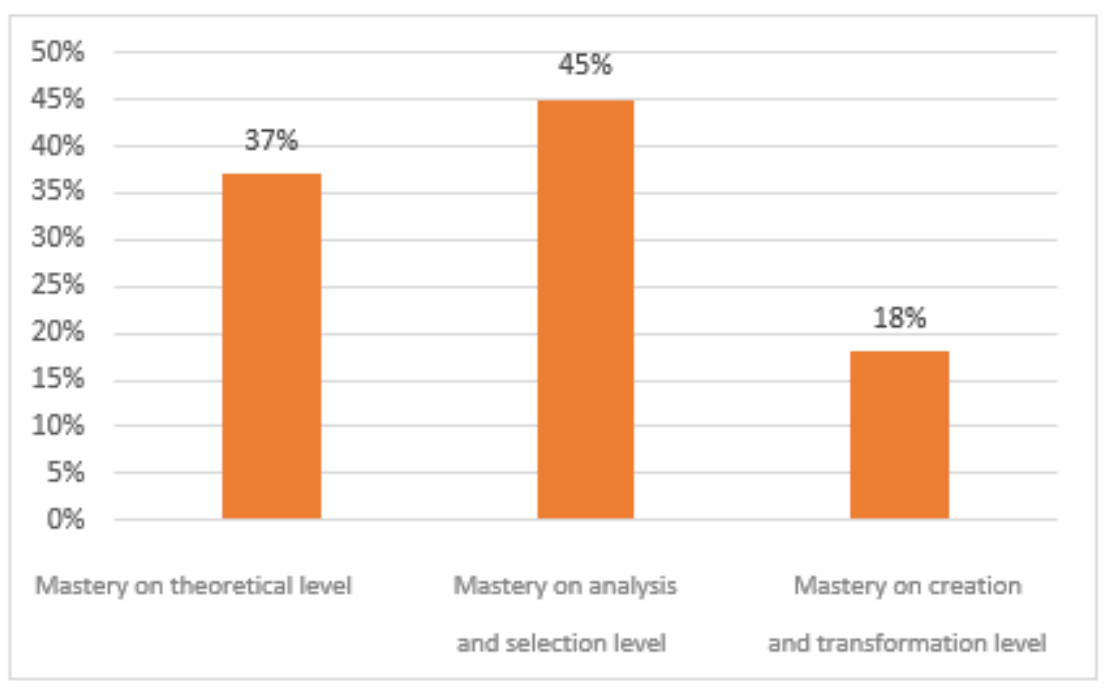

Figure 5. Dimension 3: Design and development of resources.

Figure 6 shows that, similarly, the number of teachers who claimed to be capable of using technology in an integrated way was limited, which confirmed the need to propose training that provides teachers with theoretical-practical tools, especially at the level of creation and transformation of knowledge.

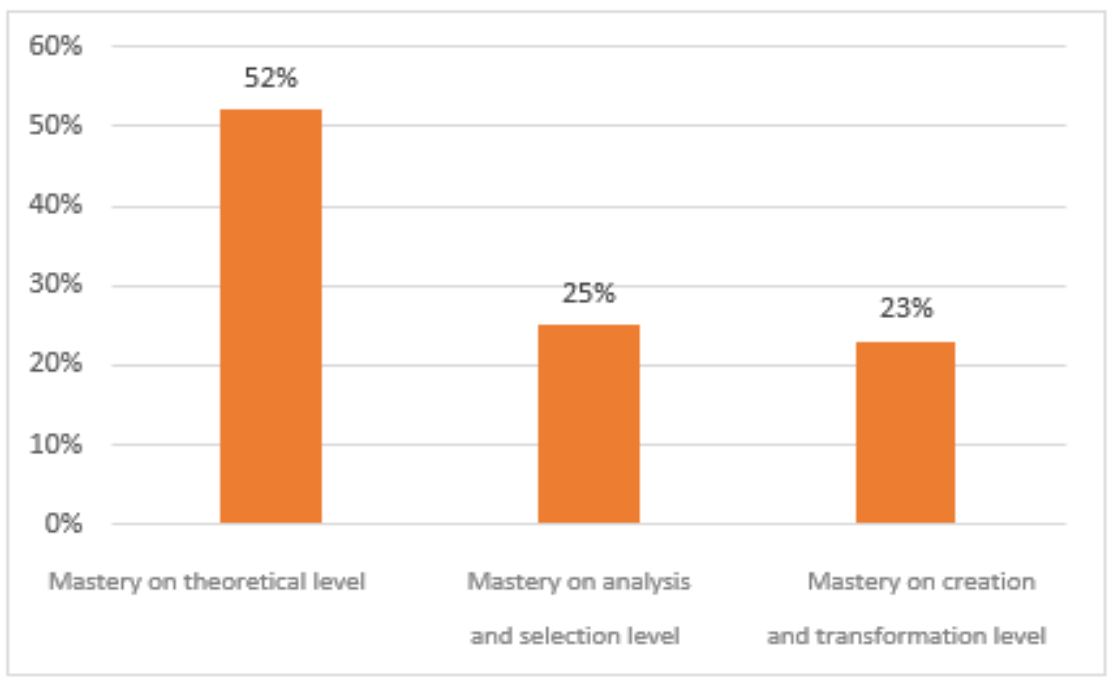

Figure 6. Dimension 4: Applying and evaluating resources.

Figure 7 shows that, regarding the relevance and possibility of integrating the pedagogical foundations of Montessori in m-learning for primary education, the participants concluded that most of the foundations were relevant and possible for integrating into the $\mathrm{m}$-learning format. This finding is fundamental, since from here, it will be possible to create sustainable environments for teaching action, both for teachers who affirm themselves capable of launching into new technologies and for those who still need to improve their teaching skills. The hybrid possibility of m-learning maintains that both profiles can be used from these tools. 


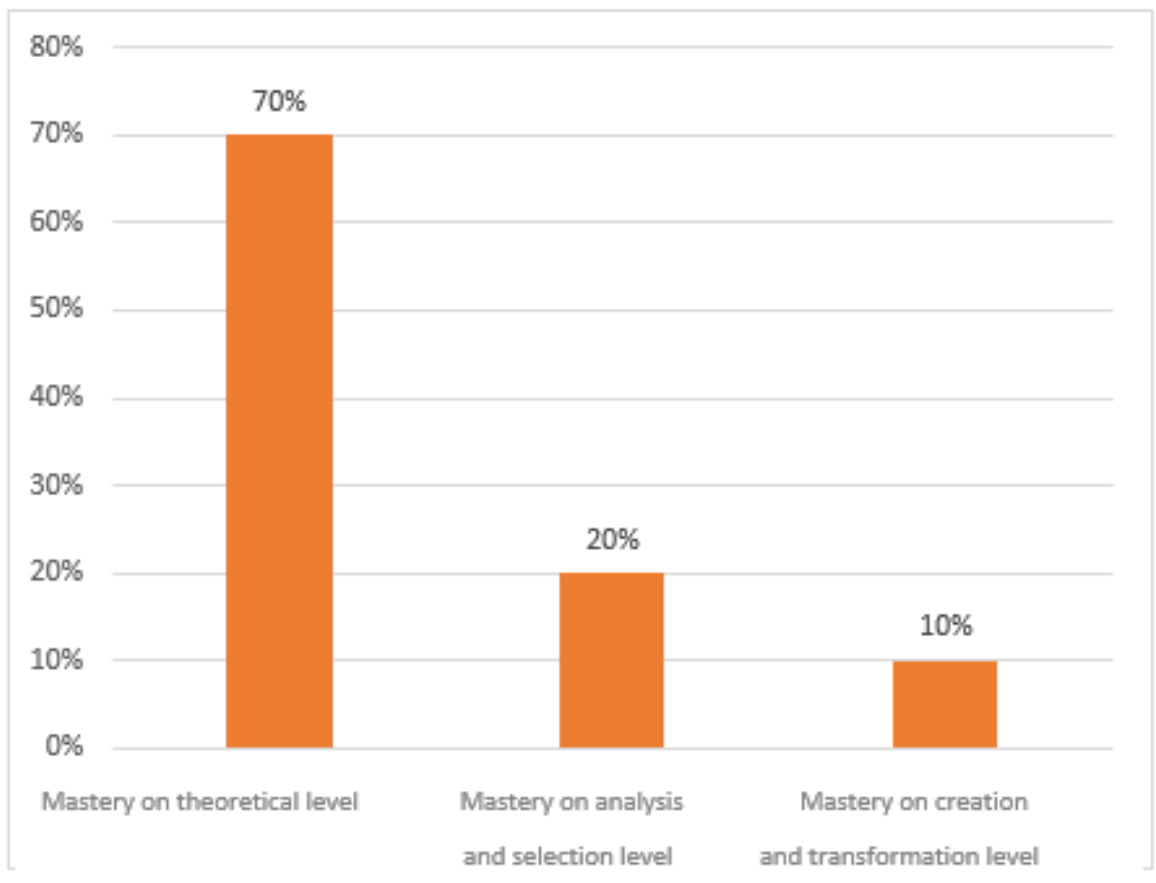

Figure 7. Dimension 5: Pertinence and integration of the principles of Montessori education.

Based on the answers to the questionnaire, this study was deepened through an open question on the relevance of the elements that the teachers considered more and less pertinent (Figure 8).

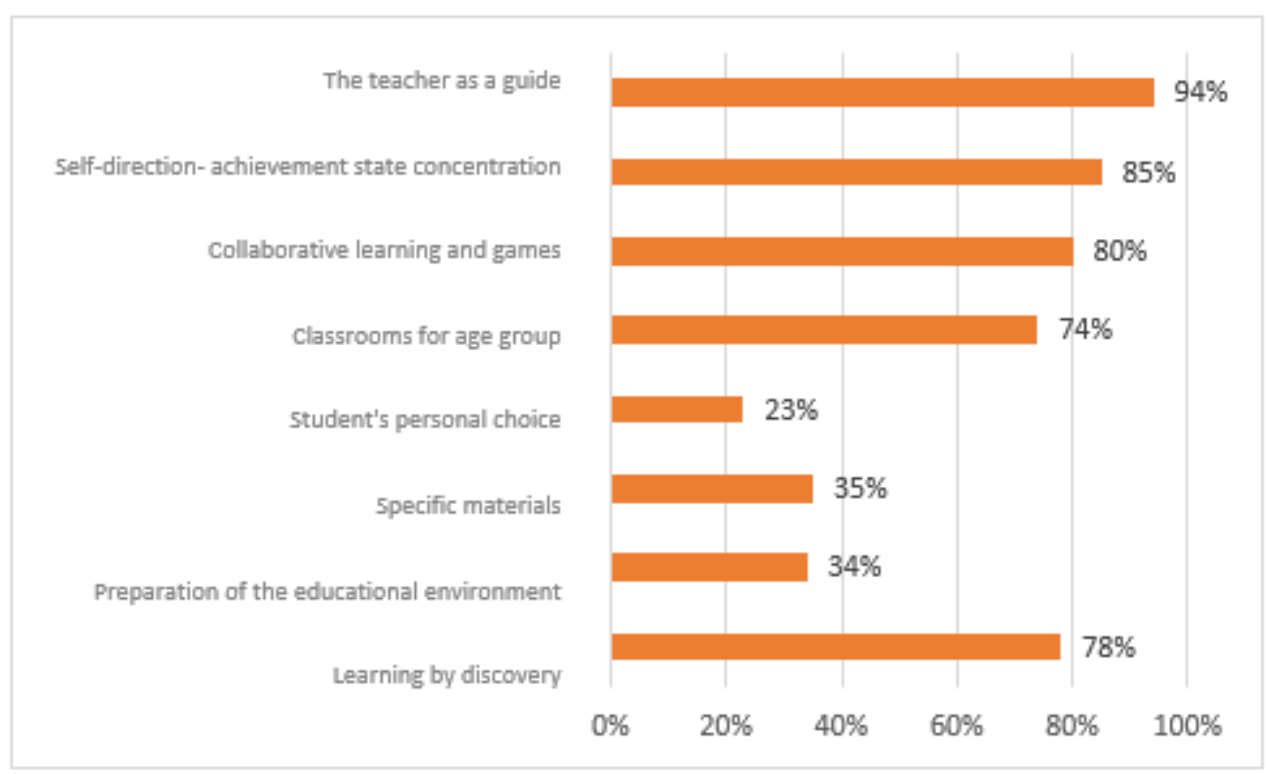

Figure 8. Relevance and possibility of integrating m-learning into primary education.

After confirmation with a degree of more than $70 \%$ of importance in most of the raised rationales, it was considered necessary to evaluate the aspects where an importance equal to or less than $70 \%$ was granted, which are described below:

- Preparation of the educational environment;

- Specific materials;

- The student's personal choice. 
The teachers reported that the educational environment and the specific materials should be flexible and that they should not be previously prepared, since children bring different and changing needs to the classroom.

Regarding the students' personal choice, the teachers argued that primary school children are not yet ready to manage their decisions, work time, or learning objectives. In this case, the last foundation, with a lower percentage of relevance considered by the teachers, would be an important aspect to deal with in the training, since the teachers who were not familiar with Montessori principles did not usually work with a high degree of autonomy in the training-learning processes, as in this method.

The results obtained in the questionnaire allowed four integrated dimensions for teacher training to be established (Figure 9).

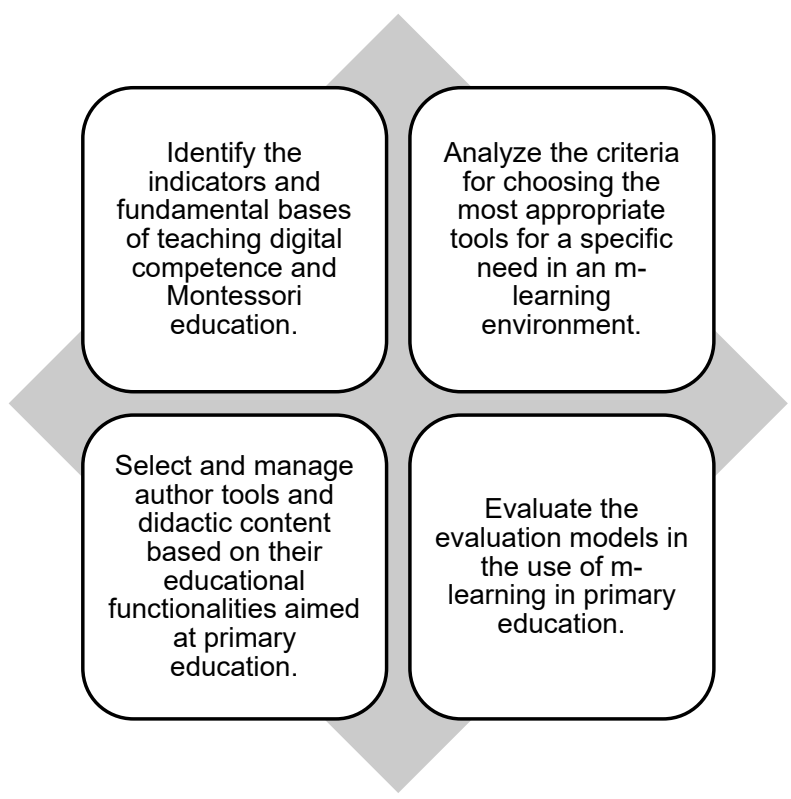

Figure 9. Integrated dimensions of teacher training.

These consolidated dimensions are the criteria that will support the teaching relationship with mobile technologies and the implementation of Montessori pedagogy in primary education. In this way, the cognitive needs of digital competences and the criteria for choosing and managing ICT tools are linked, in accordance with the contents that must be worked on, and in relation to the investigation of evaluation models for m-learning in the primary classroom.

The elements considered less relevant by teachers for the application of m-learning in primary classrooms may have been justified by the absence of education in Montessori fundamentals. For this reason, the first educational dimension emphasizes identifying the indicators and fundamental bases of both digital teaching competence and Montessori education. Preparing an environment, selecting and working with specific materials, and prioritizing students' personal choices, aspects less valued by teachers, are actions that require from a teacher both theoretical knowledge of the reasons to do it, and theoretical and practical knowledge in digital competences, so that they are able to develop a mastery of analysis, selection, creation, and transformation.

To prepare the setting, teachers should be equipped with theoretical and practical information on the importance of preparing the learning environment, which should be flexible and offer more than one possibility of interaction and learning. For this, the mastery of creation and transformation are necessary. By being trained in these principles, teachers will be able to select and/or create virtual learning environments with these characteristics. In other words, teachers who receive training in the dimensions specified within the study will be aware that it is not enough for the syllabus to use an online game 
application for their language class if, in this game, for example, the student does not have the option to choose the game's topic, path, or degree of difficulty. The teacher will understand that, in addition to being flexible, the learning environment must be previously prepared-in this case, analyzed, selected, and/or created by the teacher-so that the student can move between the different possibilities of the educational proposal, and for it to be possible to evaluate the achievement of the expected learning results in an m-learning environment activity.

From these data, it was possible to establish the training needs related to the use of m-learning from a sustainable Montessori perspective (Table 2).

Table 2. Competency areas and training needs related to the use of m-learning in primary education from a sustainable Montessori perspective.

\begin{tabular}{cc}
\hline Competency Areas & Training Needs \\
\hline Teaching digital competence & $\begin{array}{c}\text { Theoretical knowledge about } \\
\text { digital competence }\end{array}$ \\
\hline $\begin{array}{c}\text { Pedagogical tools and possibilities for } \\
\text { primary education }\end{array}$ & Analysis and selection of resources \\
\hline $\begin{array}{c}\text { Creation of interactive multimedia } \\
\text { educational content }\end{array}$ & Design and development of resources \\
\hline Evaluation of m-learning in primary education & Resource application and evaluation \\
\hline
\end{tabular}

In this case, in coherence with the Montessori principles, teachers trained under the four dimensions will have developed a more critical perception of the educational possibilities of the resources that can be applied in an m-learning format and, from the knowledge developed in the competence areas linked to the digital teaching competence, will be able to face this pedagogical and technological interrelationship in the primary classrooms.

\section{Conclusions}

Teachers perceived their competencies as stagnant and ineffective when innovating in the face of traditional pedagogical practices, dealing with unpredictable situations, or creating differentiated adaptations for an inclusive education, such as those required by Montessori pedagogical principles. Teachers perceived their digital competences to be more focused on theory and on analysis, and the selection of resources. On the contrary, it would be interesting to analyze, for example, if a teacher's country of origin has any influence on their perception of teaching.

This study confirmed the need for the development of training related to digital competencies and the ability to go beyond the selection and adaptation of resources, so that primary school teachers are able to promote innovation through technologies and, specifically, through the use of m-learning.

Regarding the fundamentals of Montessori education, the teachers considered them pertinent for the integration of m-learning in primary classes; however, they pointed out that they would need training that would link the contributions of digital competence with the Montessori elements.

Four formative dimensions were established that linked Montessori education to digital competence for $\mathrm{m}$-learning in primary education and that were considered priorities for the construction and implementation of a teacher training model that contributes to the sustainable development of education.

The next step will be to design the training, apply it, and re-evaluate teachers' perceptions of the competencies for working with m-learning in primary education.

The selection of technological means is a challenge for teachers, which requires their digital skills, their pedagogical background, and their ability to establish relationships between ICTs and the main teaching methods in order to optimize learning. However, it was not possible to evaluate the development of teaching skills and the difficulties that 
teachers may have experienced based only on the point of view of a lack of training in the use of technology. There are other factors that may prevent sustainability, such as a lack of financial access to acquire mobile technologies, little motivation in the use of technological devices, and the constant demand from the centers, which end up becoming mandatory tasks rather than teacher training processes.

The aspects addressed in this article are considered to be in tune with Sustainable Development Goals because a good quality and innovative education for the integration of ICTs is key for the sustainability of education, in particular, and for social sustainability in general.

Author Contributions: Conceptualization and methodology: M.A.B.-O., O.U.-G., A.S.-H., and J.A.-G. Software, validation, and formal analysis: M.A.B.-O., A.S.-H., O.U.-G., and J.A.-G. Project administration and funding acquisition: A.S.-H. and J.A.-G. Investigation and writing-original draft preparation: M.A.B.-O., A.S.-H., O.U.-G., and J.A.-G. Writing-review and editing: M.A.B.-O., A.S.-H. and O.U.-G. All authors have read and agreed to the published version of the manuscript.

Funding: This research is part of Project Koulu R\&D ("Towards the development of a methodology for the use of mobile phones in primary school classrooms")-ID19-XX-003, funded by SODERCAN (Society for Regional Development of Cantabria), in conjunction with CITICAN (Investigation and Technology Centre of Cantabria).

Institutional Review Board Statement: The study was conducted according to the guidelines of the Declaration of Helsinki, and approved by the Institutional Review Board of Universidad Europea del Atlántico. Protocol code: 15/2019. Date of approval: 14 June 2019).

Informed Consent Statement: Informed consent was obtained from all subjects involved in the study.

Data Availability Statement: The data presented in this study are available on request from the corresponding author. The data are not publicly available due to the conditions of the project contract with the funder (Society for Regional Development of Cantabria).

Conflicts of Interest: The authors declare no conflict of interest.

\section{References}

1. ONU. Policy Brief: The Impact of COVID-19 on Children, ONU, Geneva. 2020. Available online: https:/ /www.un.org/sites/un2 .un.org/files/policy_brief_on_covid_impact_on_children_16_april_2020.pdf (accessed on 17 October 2020).

2. Bautista Vallejo, J.M.; Hernández-Carrera, R.M.; Moreno-Rodríguez, R.; López-Bastias, J.L. Improvement of Memory and Motivation in Language Learning in Primary Education through the Interactive Digital Whiteboard (IDW): The Future in a Post-Pandemic Period. Sustainability 2020, 12, 8109. [CrossRef]

3. Cabrera, L. Efectos del coronavirus en el sistema de enseñanza: Aumenta la desigualdad de oportunidades educativas en España. Revista de Sociología de la Educación RASE 2020, 13, 114-139. [CrossRef]

4. Edelhauser, E.; Lupu-Dima, L. Is Romania Prepared for eLearning during the COVID-19 Pandemic? Sustainability 2020, $12,5438$. [CrossRef]

5. Kem-mekah Kadzue, O. Enseñanza en línea durante la crisis del Covid-19 en la educación universitaria camerunesa: Logros y desafíos. Revista Internacional Políticas Bienestar Trabajo Soc. 2020, 14, 57-74. [CrossRef]

6. Murillo, F.J.; Duk, C. El Covid-19 y las Brechas Educativas. Revista Latinoamericana de Educación Inclusiva 2020, 14, 11-13. [CrossRef]

7. Ruiz, G.R. Marcas de la Pandemia: El Derecho a la Educación Afectado. Revista Internacional De Educación Para La Justicia Soc. 2020, 9, 45-59. [CrossRef]

8. Sanz, I.; Sáinz González, J.; Capilla, A. Efectos de la Crisis del Coronavirus en la Educación; OEI: Madrid, Spain, 2020.

9. Öztürk Karataş, T.; Tuncer, H. Sustaining Language Skills Development of Pre-Service EFL Teachers despite the COVID-19 Interruption: A Case of Emergency Distance Education. Sustainability 2020, 12, 8188. [CrossRef]

10. Sánchez-Prieto, J.C.; Hernández-García, Á.; García-Peñalvo, F.J.; Chaparro-Peláez, J.; Olmos-Migueláñez, S. Break the walls! Second-Order barriers and the acceptance of mLearning by first-year pre-service teachers. Comput. Hum. Behav. 2019, 95, 158-167. [CrossRef]

11. UNESCO. Uso de TIC en Educación en América Latina y el Caribe. Análisis Regional de la Integración de las TIC en la Educación y de la Aptitud Digital (e Readiness). 2013. Available online: http://unesdoc.unesco.org/images/0021/002193/219369s.pdf (accessed on 22 April 2020).

12. Gómez Gómez, M.; Martínez Domínguez, L.M.; Paz-Albo Prieto, J.; Bailén, E.; Cordero, C.; Largo Burgos, J.; García-Velasco, I.; Calvo, J. III Estudio Sobre el Uso de la Tecnología en el Aula. Informe de Resultados. 2017. Available online: https: //www.realinfluencers.es/wp-content/uploads/2017/06/Blinklearning_informe_tic.pdf (accessed on 22 April 2020).

13. Hernández, R.M. Impacto de las TIC en la educación: Retos y Perspectivas. Propósitos y Representaciones 2017, 5, 325-347. [CrossRef] 
14. Adell, J.; Castañeda, L. Las pedagogías escolares emergentes. Cuadernos de Pedagogía 2015, 462, 1-4. Available online: https: / / www.researchgate.net/publication/314281813_Las_pedagogias_escolares_emergentes (accessed on 22 April 2020).

15. Sung, Y.T.; Chang, K.E.; Liu, T.C. The effects of integrating mobile devices with teaching and learning on students' learning performance: A meta-analysis and research synthesis. Comput. Educ. 2016, 94, 252-275. [CrossRef]

16. Crompton, H.; Burke, D.; Gregory, K.H. The use of mobile learning in PK-12 education: A systematic review. Comput. Educ. 2017, 110, 51-63. [CrossRef]

17. Ramírez-Montoya, M.S.; García-Peñalvo, F.J. La integración efectiva del dispositivo móvil en la educación y en el aprendizaje. Revista Iberoamericana de Educación a Distancia 2017, 20, 29-47. [CrossRef]

18. Jiménez de la Rosa Barrios, E.; Sandoval Caceres, I.T.; Lupiañez Gomez, J.L.; Climent Rodriguez, N.; Cázares Castillo, A. Factores y usos de tecnologías digitales en la clase de matemáticas en educación primaria. Quaderns Digitals Revista de Nuevas Tecnologías y Sociedad 2018, 86, 1. Available online: http://www.quadernsdigitals.net/datos/hemeroteca/r_1/nr_857/a_11482/11482.pdf (accessed on 22 April 2020).

19. Miranda Vázquez, A.; Senú González, I.; Santiestebán Labañino, M.M. Profesionalización de los docentes de la educación superior: Implicaciones en el desarrollo social y en la sostenibilidad de la universidad latinoamericana. Revista de Investigación, Formación y Desarrollo: Generando Productividad Institucional 2018, 6, 64-71. [CrossRef]

20. Iglesias Vidal, E.; González-Patiño, J.; Lalueza, J.L.; Esteban-Guitart, M. Manifiesto en Tiempos de Pandemia: Por una Educación Crítica, Intergeneracional, Sostenible y Comunitaria. Revista Internacional de Educación para la Justicia Social 2020, 9, 181-198. [CrossRef]

21. Colín-Mercado, N.A.; Llanes-Sorolla, L.; Iglesias-Piña, D. El sistema educativo en México, ¿visión sustentable? CoPaLa 2020, 5, 155-170. Available online: http:/ / ri.uaemex.mx/bitstream/handle/20.500.11799/105458/Sistema\%20educativo-COPALA.pdf; jsessionid=4027A4432CA095447781A1AD0BA29D81? sequence=3 (accessed on 17 October 2020).

22. UNESCO. Shaping the Future We Want: Un Decade of Education for Sustainable Development. Final Report; UNESCO: Paris, France, 2014; Available online: https://unesdoc.unesco.org/ark:/48223/pf0000230171 (accessed on 22 April 2020).

23. Boumadan, M.; Soto-Varela, R.; Ortiz-Padilla, M.; Poyatos-Dorado, C. What Factors Determine the Value of an Online Teacher Education Experience from a Teacher's Perspective? Sustainability 2020, 12, 8064. [CrossRef]

24. L'Ecuyer, C.; Murillo, J.I. El enfoque teleológico de la educación Montessori y sus implicaciones. Revista Española de Pedagogía 2020, 78, 499-518.

25. Orozco-Messana, J.; Martínez-Rubio, J.M.; Gonzálvez-Pons, A.M. Sustainable Higher Education Development through Technology Enhanced Learning. Sustainability 2020, 12, 3600. [CrossRef]

26. López Martín, R. Reflexiones Educativas para el posCovid-19. Recordando el Futuro. Revista Internacional De Educación Para La Justicia Social 2020, 9, 127-140. [CrossRef]

27. UNESCO. Competencias y Estándares TIC Desde la Dimensión Pedagógica: Una Perspectiva desde los Niveles de Apropiación de las TIC en la Práctica Educativa Docente; UNESCO: Paris, France, 2016.

28. Bosco, A. Las TIC y la educación escolar, tiempo y espacio como obstáculos o aliados de la innovación. Investigación en la Escuela 2013, 79, 43-53.

29. Drigas, A.S.; Gkeka, E.G. Montessori Method and ICTs. Int. J. Recent Contrib. Eng. Sci. IT 2016, 4, 25-30. [CrossRef]

30. Foschi, R. Maria Montessori. Ediciones Octaedro. Available online: https: / /dialnet.unirioja.es/servlet/articulo?codigo=5664437 (accessed on 1 January 2021).

31. Montessori, M.; de Sarmiento, S.L. La Educación Para el Desarrollo Humano: Comprendiendo a Montessori; Diana: México DF, México, 1979.

32. Pedró, F. La Tecnología y la Transformación de la Educación; Santillana S.A.: Santiago de Chile, Chile, 2015. 